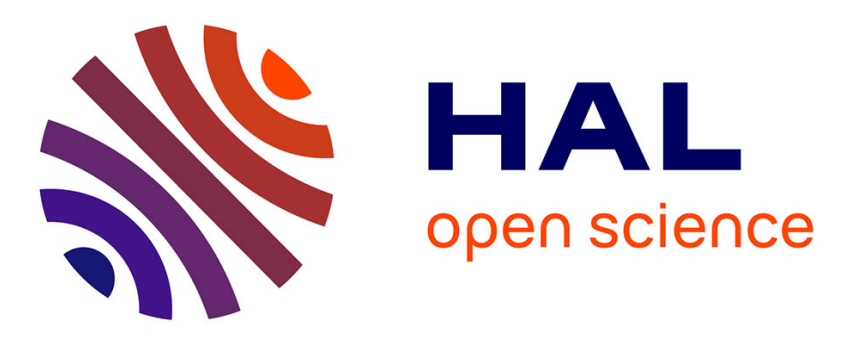

\title{
Analyzing the determinants of spatial distribution of weed control practices in a Languedoc vineyard catchment
}

\author{
Anne Biarnès, Patrick Rio, Aurélie Hocheux
}

\section{To cite this version:}

Anne Biarnès, Patrick Rio, Aurélie Hocheux. Analyzing the determinants of spatial distribution of weed control practices in a Languedoc vineyard catchment. Agronomie, 2004, 24 (4), pp.187-196. 10.1051/agro:2004018 . hal-00886012

\section{HAL Id: hal-00886012 https://hal.science/hal-00886012}

Submitted on 1 Jan 2004

HAL is a multi-disciplinary open access archive for the deposit and dissemination of scientific research documents, whether they are published or not. The documents may come from teaching and research institutions in France or abroad, or from public or private research centers.
L'archive ouverte pluridisciplinaire HAL, est destinée au dépôt et à la diffusion de documents scientifiques de niveau recherche, publiés ou non, émanant des établissements d'enseignement et de recherche français ou étrangers, des laboratoires publics ou privés. 


\title{
Analyzing the determinants of spatial distribution of weed control practices in a Languedoc vineyard catchment
}

\author{
Anne BIARNÈS ${ }^{\mathrm{a}}$, Patrick RIO ${ }^{\mathrm{b}}$, Aurélie HocHEUX ${ }^{\mathrm{a}}$ \\ a IRD, UMR LISAH, 2 place Viala, 34060 Montpellier, France \\ ${ }^{\mathrm{b}}$ INRA, UMR LAMETA, 2 place Viala, 34060 Montpellier, France
}

(Received 10 January 2003; accepted 20 May 2003)

\begin{abstract}
Characterization of the spatial organization of agricultural practices is required for an assessment of the risks of diffuse pollution by pesticides. In the case of a vineyard catchment in Southern France, the authors hypothesized that the diversity of weed control practices is spatially organized at different levels. The practices were characterized on the basis of interviews with 27 vine-growers belonging to two different wineries. Three practices were differentiated according to the intensity of herbicide use. The results showed that field characteristics related to inter-row width play an important role in the weed control choices but fully make sense in the context of the holding, where choices of practices are related to the size of the workforce and the structure of the vineyard. The supply basin of a co-operative winery appeared as a third level of organization of the practices as the wineries direct the structure of their members' vineyards through their incentive policy. Finally, the possibility of using the results to localize weed control practices is discussed.
\end{abstract}

vine-growing / Languedoc / weed control practices / spatial organization / risks of diffuse pollution

\section{INTRODUCTION}

Assessment of the risks of diffuse water pollution associated with cropping practices is a topic of current concern in numerous countries, owing to the growing use of pesticides and fertilizers since the 1950s [14, 25]. In Southern France, the regional water quality inventories conducted from 1999 to 2001 $[1,2]$ show that surface water of the overall observation network and more than $80 \%$ of the subterranean water of the same network are contaminated. $65 \%$ and $80 \%$, respectively, of the active matters found in surface and subterranean water are herbicides. The knowledge of water contamination processes indicates that this pollution should be seen in relationship to the importance of vine-growing and the high risks of herbicide leaching in a Mediterranean climate. The pollution measurable at the catchment outlet is in fact related to the transport of the active matter by runoff during heavy rainfall events [19, 20,21].

This knowledge assigns a crucial role to vineyard weed control practices. There are two main methods of weed control: integral chemical weed control of the field and partial chemical weed control. In the first case herbicides are sprayed on the rows and inter-rows of vine. The partial chemical weed control combines chemical weed control of the rows and of possibly part of the inter-rows with repeated surface tillage of the interrows that do not receive herbicides. On average, partial chem- ical weed control uses 30 to $60 \%$ less herbicide than integral chemical weed control.

The choice of a weed control method and the dates on which the different operations are carried out are particularly implicated in the pollution process: tillage or no tillage, the dates of the different tillage affect the hydraulic conductivity of the soil surface and the volume of runoff water at the field outlet, while the doses and dates of herbicide-spreading influence the dissipation of the active matter through the effect of micro-organisms and determine the concentration of herbicides in the runoff water.

However, the knowledge obtained about the pollution processes tends to show that, in order to assess the risks of diffuse pollution, a good representation of the importance of each type of practice and the spatial localization of each is required $[4$, $9,16,23]$. This representation could be obtained by regular observations of soil surface characteristics and exhaustive survey of the farmers concerned. In practice, such observations and survey are not realizable because of the time they would require. Another way is to look for indicators related to field characteristics, holding structures and economic environment to assess the diversity of practices and the probable spatial localization of each.

This is what we propose to do in the case of a vineyard catchment in Southern France (Hérault Department). The catchment,

* Corresponding author: biarnes@ensam.inra.fr 
about $100 \mathrm{~km}^{2}$ in area, suffers from serious pollution of the surface water by herbicides.

In the present article, we examine the choices of the dominant weed control methods, as defined above, which determine the intensity of herbicide use. We ask (1) what are the determinants of these choices and (2) whether these determinants can be geographically localized.

We explore three possible levels of spatial organization of the diversity of the weed control practices: the field, the farm holding and its land, and the co-operative winery and its supply basin. Our hypotheses regarding the choice of the explored levels of organization and the resulting methodological choices are described in the following two Sections. The results of this exploration are presented in Section 4. In the final section, the possibility of using the results to localise weed control practices, and the question of the appropriate level of data spatialization in order to assess the pollution risks at a catchment outlet are discussed.

\section{HYPOTHESES REGARDING THE LEVELS OF SPATIAL ORGANIZATION OF WEED CONTROL PRACTICES IN THE VINE-GROWING AREA OF SOUTHERN FRANCE}

With 298000 ha of vineyards (i.e. a third of the regional UAA) concentrated in the coastal plain and the foothills of the mountainous massifs, Languedoc-Roussillon is the largest vine-growing region in France. It is characterized by the heterogeneity of its vineyard, the strong diversity of structure of the holdings and the importance of co-operative wineries in the organization of the industry. We hypothesized that these three characteristics are likely to structure the diversity of the weed control practices.

\subsection{The field, the farm holding and its land}

At the local or micro-regional level, which is the level concerned here, the field and the farm holding and its land are often advanced as the favored levels of spatial organization of farming activities $[12,17,26]$.

\subsubsection{Field determinants}

The field constraints restrict the technical choices. In the case of vineyard weed control, we can assume that these constraints are related to topographic position, soil type and planting structure.

The central vine-growing plain of the Languedoc, where our study is located, presents a succession of geomorphological units that, according to Bonfils [6], determine the distribution of the different soils in the landscape. These soils have contrasting properties, particularly in terms of surface texture, and can therefore influence the choice of weed control practices.

One of the characteristics of the Languedoc vineyard is its heterogeneity. This results from gradual replanting associated with the major transformations that have radically changed vine-growing in the region over the last century [31]. Starting with the appearance of the first vineyard tractors in the 1960s, ever-greater mechanization has necessitated an increase in inter-row widths and changes in vine training (conversion from bush vines to wire-trained vines). Then, the switch from massproduction to quality wines since the 1970s has been accompanied by a renewal of the grape varieties. The traditional varieties have been partially replaced by what are termed "aromatic" varieties. At the present time, $50 \%$ of the regional vineyard is planted in aromatic varieties [11]. In holdings that have not completed their transformation, fields of old bushpruned vines, planted equidistantly from one another with inter-plant spacing of 1.6 or even $1.5 \mathrm{~m}$, grow side by side with fields of younger vines, wire-trained and planted in aromatic varieties in spaced rows ( $2 \mathrm{~m}$ or $2.5 \mathrm{~m}$ apart). Between the two, we find fields of bush vines or wire-trained vines with intermediate spacing.

Inter-row heterogeneity is a constraint on soil management. The inter-row width determines both the minimum size of the tools that can pass between the rows and ease of work. Only tools under $1 \mathrm{~m}$ wide can be used if the inter-row width is $1.6 \mathrm{~m}$ or under. Such widths were suitable for animal traction but make it difficult for tractors to pass easily. The risks of damaging the harvest by knocking against the clusters as the tractor passes are high from June onwards, particularly in bush-pruned fields.

\subsubsection{Holding-related determinants}

Different studies have shown that crop management choices are not made on the scale of the individual field but on that of sets of fields with possibly different characteristics, such as soil type, variety, etc. [3, 27]. The idea of "sets of fields" shows the effect of an endeavor to simplify the work, which takes us back to the structural constraints or to the methods of operation of the holding. The possibility of associating these farms' characteristics with the technical choices has often been emphasized $[8,17]$. In particular, economic constraints and work organization-related constraints associated with the availability of equipment and labor are frequently advanced to explain the diversity of practices among farmers $[10,22,28]$. As a result, economic and organizational constraints can mask some or all of the field constraints and be reflected in different technical choices for the land of different farms.

In the case of the Languedoc, the small average size of the holdings covers major structural differences. According to the last farm census [11], 54\% of the holdings cultivate under 5 ha of vines and only $14 \%$ over 20 ha. In terms of area, the former represent only $8 \%$ of the Languedoc vineyard while the latter represent $52 \%$. Because of the concentration of vines in localized areas of production, $88 \%$ of these holdings specialize in vine-growing. There are numerous retired people and smallholders whose main business activity is not farming. In 2000, they represented $21 \%$ and $28 \%$, respectively, of vineyard managers.

Because of these differences in size of holding and the status of the vineyard manager, we hypothesized that there is a diversity of production resources (equipment and labor) and that this diversity has an effect on the choice of weed control methods.

In particular, there are differences in workload, depending on the techniques chosen. Integral chemical weed control is a costly technique as it involves the purchase of greater volumes of herbicides than are required for partial chemical weed 


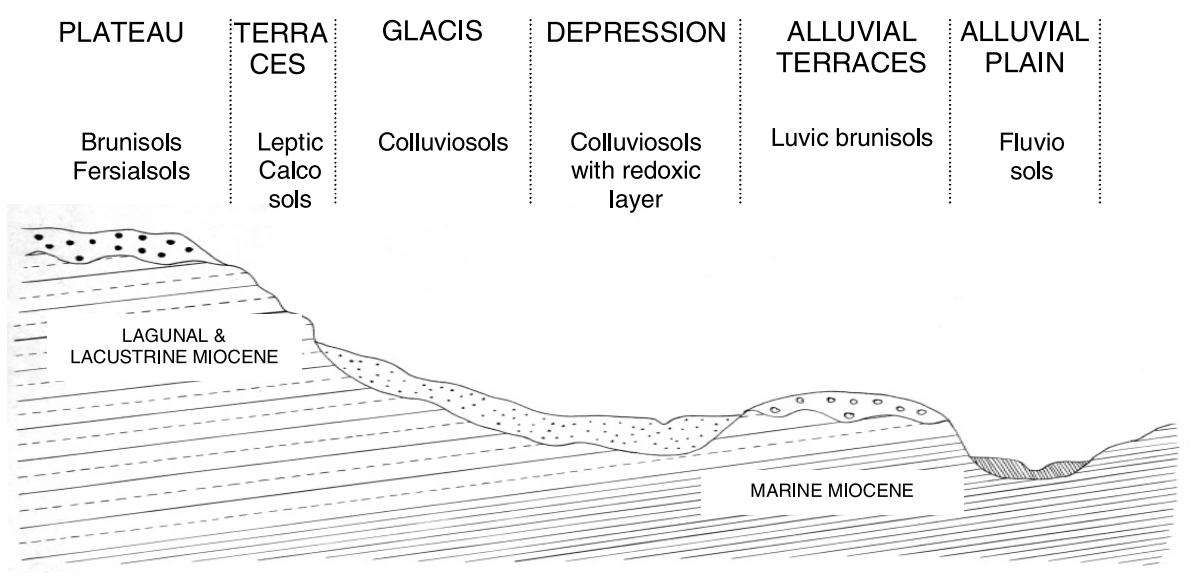

Figure 1. The different geomorphological and pedological units of the Peyne valley [15].

control. However, it involves far less work, as it reduces the number of passes between the vines, particularly in the very busy spring and early summer period of the year. The choice of a weed control technique will therefore be extremely sensitive to the marginal cost that the vine-grower attributes to an hour of weed control work. One can hypothesize that the marginal cost is not necessarily the same for all fields in the holding because of the high variability of raw margins according to the fields and the grape varieties.

\subsection{The co-operative winery and its supply basin}

The field and the land of the holding are probably not the only levels at which the diversity of the practices are spatially structured. In the case of vine-growing in the Languedoc, the supply basin of a co-operative winery ${ }^{1}$ can also be a structuring level as it often covers a more or less continuous area in which the grape variety characteristics are relatively homogeneous. In fact, co-operatives have considerable weight in the industry: in 1997, they were responsible for grape collection in over $70 \%$ of the Hérault vineyard [31]. In this department, almost 20000 vine-growers are members of one or more co-operative wineries, to which they are obliged to deliver their entire production. In most cases, the supply basin of a co-operative winery extends over some or all of the vine-growing land of one or more communes. The co-operatives direct the structure of their members' vineyards through their incentive policy regarding change of grape variety and through their pricing policy, which determines the payment that the vine-growers receive [13]. They can therefore indirectly influence the choices of weed control practices in their supply basin.

\section{MATERIALS AND METHODS}

\subsection{Study area}

The catchment studied is the Peyne catchment in the lower Hérault Valley. It covers an area of about $100 \mathrm{~km}^{2}$ including

\footnotetext{
1 The term "supply basin" is used here in the sense defined by Caneill and Le Bail $[7,18]$ i.e. the intersection between a production basin and an enterprise's collection basin.
}

8000 ha of UAA and intersects the land of 7 communes. It is a vine-growing catchment characteristic of vine-growing in the Languedoc plain. Its relief is varied (maximum altitude: $280 \mathrm{~m}$, minimum altitude: $17.5 \mathrm{~m}$ ) and one can find there the soil diversity of the central vineyard plain of the Hérault Department described by Bonfils $[6,15]$ with the RP classification: leptic calcosols and colluviosols on Miocene sediments with a finesandy loamy clayey to loamy fine-sandy clayey texture; brunisols and fersialsols from old alluvial deposits on stony plateaux, with a coarse-sandy clayey to clayey coarse-sandy texture (Fig. 1).

Five co-operatives collect the production of the vine-growers within the catchment. Inquiries made of the managers of the co-operative wineries in our study area show differences between the co-operatives in their incentive policy regarding change of grape variety. These are reflected in differences in the levels of change of variety on the supply basin scale.

\subsection{Data collection}

\subsubsection{Composition of sample of vine-growers to be surveyed}

A sample of 27 farm holdings was made with the aim of covering a diversity of rate of change of vine varieties, a diversity of area of land, and a diversity of localization of fields. These criteria were easy to vary in the sample and are, according to our hypotheses, good determinants of a variation of the weed control practices.

From the five co-operative wineries, we selected two - wineries $\mathrm{A}$ and $\mathrm{B}$ - characterized by as different as possible rates of change of variety in their supply basin and whose supply basins cover the scope of soil types recorded in the Peyne Valley. Until the end of the 1990s, winery A had opted to maintain mass-production of inexpensively produced wines and therefore did little to encourage the restructuring of its members' vineyards. Today, its supply basin is characterized by the lowest rate of change of variety in the Peyne catchment (35\%). In contrast, winery B embarked on converting its vineyard early on and at present the grape varieties have been changed in $55 \%$ of its supply basin. 
The sample of vine-growers was distributed between the two wineries: 14 vine-growers are members of winery A and 13 of winery $\mathrm{B}$. The vine-growers were selected from the lists of the winery membership (winery B) or the harvest declarations obtained from the mayor's office (winery A). In order to cover the regional diversity of farm holdings without over-representing the small farms, these were selected by stratified drawing in four area classes: under 4 ha, 4 to 10 ha, 10 to 20 ha and over 20 ha under vines. The 4 ha limit represents the minimum area for a holding, while the 20 ha limit corresponds to the holding model recommended by the Chamber of Agriculture of the Hérault Department in the 1990s (one man per 20 ha). We arbitrarily chose an intermediate limit to break up the sample better. In each winery, between three and four vine-growers per class were surveyed.

\subsubsection{Content of survey questionnaire}

The survey questionnaire was divided into two complementary parts. Part 1 concerned the description of the weed control practices used in the vineyard of the holding and of the area covered by each practice. Part 2 concerned the description of the variables likely to explain the choice of these practices. Within these variables, a distinction was made between the characteristics of the fields where each type of practice was used and the variables relating to the structure of the holding.

The field characteristics taken into account systematically concerned mode of vine training (bush or wire-trained vines), type of grape variety (traditional or aromatic), the inter-row width and possible characteristics left to the choice of the vinegrower in order to explain his choices (presence of surface roots, slope, field localization, field size, soil type, etc.).

The holding structure characteristics taken into account concerned both the vineyard characteristics (distribution of area by vine training, inter-row width and type of grape variety) and the traction and tillage equipment and available non-harvest workforce.

To reduce the duration of the survey, the data were recorded field by field in only 13 holdings, distributed between the two co-operative wineries in order to cover a diversity of location of fields and soil types. The fields of these holdings were localized on a 1/25000 topographical map, enabling us to obtain data on soil type. To do so, each field was assigned the corresponding soil unit on the 1/100 000 map of Bonfils [6]. For the other 14 holdings of our sample, the data were recorded on the scale of the group of fields with the same characteristics.

\section{RESULTS}

\subsection{Diversity and respective importance of weed control practices in the holdings sample}

In order to differentiate weed control practices according to the intensity of herbicide use, we distinguish, on the one hand, integral chemical weed control (method M1) and, on the other hand, two sub-methods of partial chemical weed control (submethods M2a and M2b). In sub-method M2a, spraying of herbicide only concerns the rows, while tillage concerns all the inter-rows. In sub-method M2b, herbicide is sprayed on the
Table I. Percentage of the different weed control practices in the sample of surveyed holdings.

\begin{tabular}{lcccccc}
\hline $\begin{array}{l}\text { Weed control } \\
\text { methods }\end{array}$ & \multicolumn{2}{c}{ Fields concerned* } & Area concerned & \multicolumn{3}{c}{$\begin{array}{c}\text { Vine-growers } \\
\text { concerned }\end{array}$} \\
\cline { 2 - 7 } & Number & $\%$ & Ha & $\%$ & Number & $\%$ \\
\hline M1 & 164 & 41 & 125 & 32 & 23 & 85 \\
M2a & 112 & 28 & 139 & 36 & 10 & 37 \\
M2b & 122 & 31 & 124 & 32 & 9 & 33 \\
Total & 398 & 100 & 388 & 100 & $27 * *$ & 100
\end{tabular}

* assessed on the basis of average areas by inter-row width;

** number of vine-growers surveyed. Vine-growers using one or two weed control methods, the total of vine-growers concerned by each practice is superior to the number of vine-growers surveyed.

Table II. Distribution of weed control practices by inter-row width.

\begin{tabular}{lcccccc}
\hline Inter-row width & \multicolumn{2}{c}{ M1 } & \multicolumn{2}{c}{ M2 } & \multicolumn{2}{c}{ Total } \\
\cline { 2 - 7 } & Ha & $\%$ & Ha & $\%$ & Ha & $\%$ \\
\hline $\mathrm{L} \leq 1.6 \mathrm{~m}$ & 77 & 89 & 10 & 11 & 87 & 100 \\
$\mathrm{~L}>1.6 \mathrm{~m}$ & 48 & 16 & 254 & 84 & 302 & 100 \\
\hline
\end{tabular}

rows and some of the inter-rows, while tillage is only used in the other inter-rows. In this last case, the inter-rows under chemical weed control are used to carry out spraying of pesticides during spring and summer. The absence of tillage in these inter-rows is aimed at ensuring a good bearing capacity. With sub-method M2a, the herbicides are spread on average over $50 \%$ to $65 \%$ of the field surface, as against only $30 \%$ with submethod M2b.

In our sample, method M1 is used by $85 \%$ of the vine-growers surveyed, on $41 \%$ of the fields and over $32 \%$ of the area (Tab. I). Sub-methods M2a and M2b are used in equivalent proportions. In total, they are used by $70 \%$ of the vine-growers, on $59 \%$ of the fields and over $68 \%$ of the area.

The number of fields in which the different practices are used was assessed on the basis of average field areas according to inter-row width. These areas were calculated on a sample of 193 fields belonging to the 13 holdings for which we had field by field data. In these holdings, the average area of a field of vines is $1 \mathrm{ha}$, with significant differences according to inter-row width: 0.67 ha for fields with narrow inter-rows, 0.77 ha for fields with intermediate inter-rows and 1.37 ha for fields with wide inter-rows. These differences can be explained by the consolidation that usually accompanies new plantations.

\subsection{Distribution of weed control practices by field characteristics}

As we hypothesized and if one confines oneself to the most aggregate level of the practices (M1 and M2), analysis of the distribution of the weed control practices by field characteristics shows "inter-row width" as the explanatory variable for a large part of the observed diversity (Tab. II). $89 \%$ of the area of vines with narrow inter-rows is under integral chemical weed control (M1 method). Inversely, $84 \%$ of the area under vines 
Table III. Distribution of weed control practices by soil type.

\begin{tabular}{lcccc}
\hline Soil & $\begin{array}{c}\text { Number of } \\
\text { fields }\end{array}$ & \multicolumn{3}{c}{ Weed control practice } \\
\cline { 3 - 5 } & & M1 (\%) & M2a (\%) & M2b (\%) \\
\hline $\begin{array}{l}\text { Brunisols, fersialsols, luvic } \\
\text { brunisols }\end{array}$ & 89 & 34 & 46 & 20 \\
$\begin{array}{l}\text { Leptic calcosols } \\
\text { Colluviosols and colluviosols }\end{array}$ & 38 & 42 & 34 & 24 \\
with redoxic layer & 19 & 47 & 32 & 21 \\
Total & 146 & 38 & 42 & 21 \\
\hline
\end{tabular}

with wider inter-rows is under partial chemical weed control (M2 method).

Other field characteristics were advanced by the vine-growers to justify their choices of integral chemical weed control: slope, field location (isolated field with wide inter-rows in the midst of fields with narrow inter-rows), field size and shape (which can make it difficult for a tractor to pass), presence of surface roots associated with a long absence of cropping, and a specific problem of difficult weed control. In our sample, the slope always intersects the "narrow inter-row" variable, and the other field characteristics only concern 4.2 ha of vine with over 1.6-m wide inter-rows ( $1 \%$ of the total area of vine in the sample).

Distribution of the weed control methods and sub-methods by soil type was carried out on the 146 fields of the 13 holdings for which we have field scale data. Owing to the low number of fields of luvic brunisols and of colluviosols with a redoxic layer we brought together the fields with similar soil in regard to properties of interest (Tab. III). Analysis of the data by a chisquared test did not indicate soil type as a criterion to differentiate the practices.

\subsection{Distribution of weed control practices by the vineyard characteristics of the holdings}

On the basis of the previous results, we examined the distribution of weeding practices at the level of the vineyard of the holdings to check the effect of the holdings on the stability of the relation between width of inter-rows and choice of weed control methods M1 and M2. Figure 2 represents, for each farm holding, the relationship between the percentage of the area under vines with wide and intermediate inter-rows and the percentage of the area under partial chemical weed control (method M2). As shown in this figure, choices regarding weed control practices are not strictly related to the spacing characteristics of the fields for all vine-growers:

- a strict relationship exists for only ten vine-growers;

- in the case of six vine-growers, the area under partial chemical weed control is smaller than the area under vines with over 1.6-m wide inter-rows. Some widely spaced vines are under integral chemical weed control. These technical choices are related to the other field constraints mentioned earlier (four vine-growers) or to the absence of tillage equipment suitable for vines with intermediate inter-rows (two vine-growers);

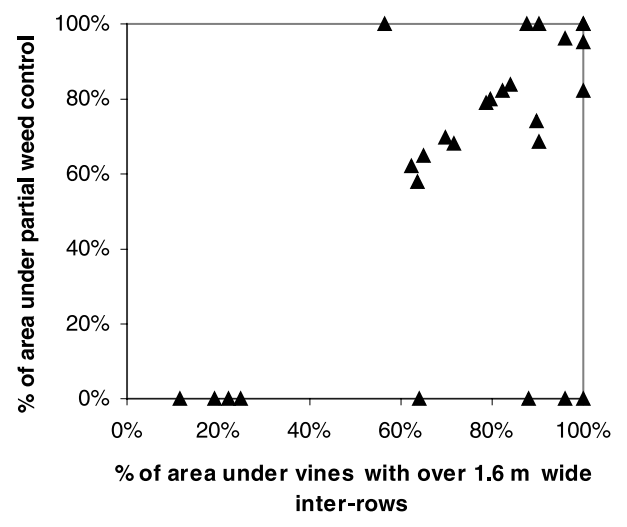

Figure 2. Relationship between percentage of area under vines with over 1.6- $\mathrm{m}$ wide inter-rows and percentage of area under partial chemical weed control in the vineyard of the holdings.

- most importantly, some vine-growers (eight and three, respectively) use method $\mathrm{M} 1$ or method $\mathrm{M} 2$ on all their fields regardless of spacing. For four of the vine-growers who use integral chemical weed control on all their fields, the overall structure of their vineyard appears to exert an effect. They all have a very low proportion of vines with wide inter-rows (under 25\%). It is as if these vine-growers use the same method for all their vines in order to simplify the work, the selected method being defined by the strongest constraint: that related to the presence of narrow interrows. Here we find a technical behavior linked to methods of managing the whole area under a crop and described for annual and perennial crops by various authors [3, 5, 27].

\subsection{Distribution of weed control practices by the structural characteristics of the holdings}

In this approach, we favored the choice of the dominant weed control practice. The vine-growers were divided into 3 groups (GM1, GM2a and GM2b) according to their dominant practice (Tab. IV). The groups contain eight, ten and nine vinegrowers, respectively. It should be noted that vine-growers using partial chemical weed control do not combine sub-methods M2a and M2b in their vineyard.

According to our initial hypotheses, the holding characteristics used to explain the weed control choices and hence the distribution of the holdings between the different groups are: age of vineyard manager, vineyard structure (percentage of total area under vines of different types by inter-row width, type

Table IV. Distribution of weed control practices by group of holdings (in percentage of total area of holdings under vines).

\begin{tabular}{lcccc}
\hline Group & \multirow{2}{*}{$\begin{array}{c}\text { Number } \\
\text { of vine-growers }\end{array}$} & \multicolumn{3}{c}{ Weed control practice } \\
\cline { 3 - 5 } & 8 & M1 (\%) & M2a (\%) & M2b (\%) \\
\hline GM1 & 10 & 100 & 0 & 0 \\
GM2a & 9 & 11 & 76 & 0 \\
GM2b & 9 & 0 & 89
\end{tabular}




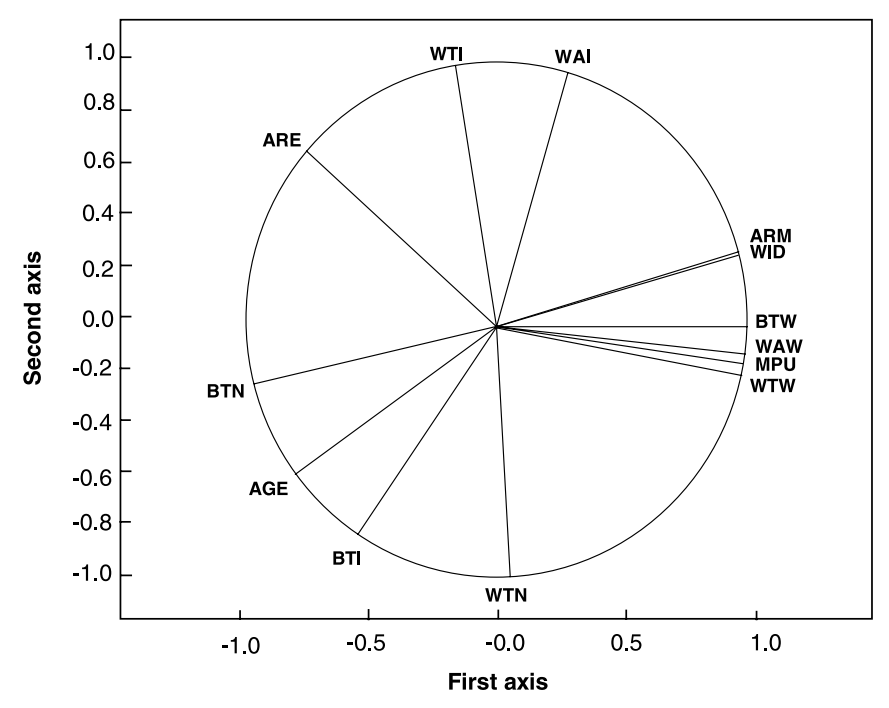

Figure 3. Circle of correlation between the variables and the axes of the discriminant factorial analysis.

BTN: \% of area under bush-pruned traditional varieties in fields with narrow inter-rows (bush-pruned traditional narrow); WTN: \% of area under wire-trained traditional narrow; BTI: \% of area under bushpruned traditional intermediate; WTI: \% of area under wire-trained traditional intermediate; BTW: \% of area under bush-pruned traditional wide; WTW: \% of area under wire-trained traditional wide; WAI: $\%$ of area under wire-trained aromatic intermediate; WAW: $\%$ of the area under wire-trained aromatic wide; ARM: $\%$ of area under aromatic varieties; WID: \% of area under vines with > 1.6-m wide inter-row spacing; MPU: non-harvest manpower unit; ARE: area per non-harvest manpower unit; AGE: age of farmer.

of grape variety and vine training), available non-harvest workforce (in MPUs), area under vines per MPU and available equipment (presence or absence of tillage equipment for vines with different inter-row widths).

The available equipment is the only discrete variable of all our variables. So we analyzed it independently of the others. The analysis showed that it could be only slightly implicated in the determination of the group to which a holding belongs. All vine-growers have tillage equipment. Only five of the 17 vine-growers using integral chemical weed control in all or part of their vineyard do not have equipment narrow enough to pass between vines with narrow or even intermediate inter-rows. All five belong to groups GM2a and GM2b.

A direct search for the discriminant variable combinations of the three groups of holdings was conducted on the other variables by discriminant factorial analysis (DFA). The high values obtained for the pseudo-Fisher classifiers calculated for each of the DFA axes indicate the pertinence of this approach. With values of 66.04 and 8.9, respectively, they are significantly higher than the highest coefficient obtained from the analysis of variance applied to each variable individually (5.87 for the MPU variable).

The discriminant space obtained is interpreted on the basis of the correlation of the original variables with the discriminant axes calculated at the mean point of the groups [30]. The first axis is related to workforce size, the relative importance of the

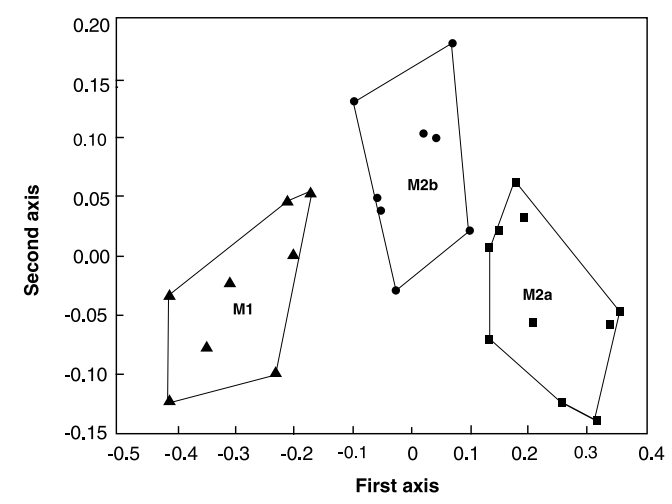

Figure 4. Representation of items in the plane of the discriminant factorial analysis.

areas planted in aromatic varieties, the high proportion of wiretrained surfaces and the percentage of surfaces planted with over 1.6-m wide inter-rows (Fig. 3). The variable MPU being linked to the total area of vineyard by a coefficient of correlation of 0.8 , we can consider that the first axis represents the dimension and rate of modernization of the holdings. On the right of the figure are localized large vine-growing structures characterized by a high rate of change of varieties. On the left are localized little structures with a high proportion of bush-pruned traditional varieties with narrow inter-rows. The second axis is related to the relative size of the area under wire-trained traditional varieties with narrow inter-rows and bush-pruned traditional varieties with intermediate inter-rows. These structural characteristics reflect a certain accommodation with changes in vine training: development of traditional types of training or early renewal inconsistent with the vine training developed from the 1970s onwards.

Figure 4 represents the position of items in the plane of the discriminant factorial analysis. Its centre of gravity is occupied by the group of vine-growers for whom weed control in the rows only is the dominant practice - group M2b. Away from the centre of gravity, there is an intensified use of herbicides in the presence of large structures where there has been a change of variety - group M2a, or because of a small workforce and/ or narrow inter-rows in aging structures - group M1.

It should be noted that there were a few reclassifications ( 3 of the 27 observations, i.e. $11 \%$ ) when the observations were assigned to their most likely group according to the discriminant factors. Such reclassifications occur between groups GM2a and GM2b (Tab. V). They do not affect the distribution

Table V. Classification of a priori and a posteriori observations.

\begin{tabular}{lcccc}
\hline $\begin{array}{l}\text { A priori } \\
\text { classification }\end{array}$ & \multicolumn{4}{c}{ A posteriori classification } \\
\cline { 2 - 5 } & M1 & M2a & M2b & Total \\
\hline M1 & 8 & 0 & 0 & 8 \\
M2a & 0 & 8 & 1 & 9 \\
M2b & 0 & 1 & 9 & 10 \\
Total & 8 & 9 & 10 & 27 \\
\hline
\end{tabular}


Table VI. Structural characteristics of groups for the most discriminant variables of the analysis.

\begin{tabular}{lcccccccccc}
\hline Group & \multicolumn{9}{c}{ Variables } \\
\cline { 2 - 11 } & BTN* & WTN & WTI & BTW & WTW & WAI & WAW & ARM* $^{*}$ & WID* & MPU* \\
\hline GM1 & 43.9 & 2.8 & 10.8 & 0.6 & 7.2 & 3.1 & 22.8 & 25.9 & 53.3 & 0.7 \\
GM2a & 11.4 & 3.3 & 10.8 & 3.2 & 7.3 & 5.4 & 50.3 & 56.3 & 84.6 & 1.8 \\
GM2b & 18.2 & 1.6 & 16.4 & 1.1 & 6.2 & 15.9 & 35.4 & 51.3 & 80.2 & 1.2 \\
Total & 23.5 & 2.5 & 12.9 & 1.7 & 6.9 & 8.6 & 36.6 & 45.4 & 73.7 & 1.3 \\
\hline
\end{tabular}

* discriminant variables at the $5 \%$ threshold by an analysis of variance.

Table VII. Distribution of vine-growers between the three groups of holdings by cooperative winery membership.

\begin{tabular}{lccc}
\hline Group & \multicolumn{3}{c}{ Number of vine-growers } \\
\cline { 2 - 4 } & Winery A & Winery B & Total \\
\hline M1 & 7 & 1 & 8 \\
M2a & 3 & 6 & 9 \\
M2b & 4 & 6 & 10 \\
Total & 14 & 13 & 27 \\
\hline
\end{tabular}

of the holdings between groups GM1 and GM2a or b, which underlines the robustness of the discrimination between these groups.

The characteristics of the different groups are summarized in Table VI, which presents the average values of the most discriminant variables of the analysis, for each group. The variables that show the greatest contrast between group GM1 and groups GM2a and GM2b are "non-harvest manpower unit" (MPU), "percentage of aromatic varieties" (ARM), "percentage of vines with over 1.6-m wide inter-rows" (WID) and "percentage of bush-pruned vines with narrow inter-rows" (BTN). The low value of the MPU variable in the first group is related to the high percentage of part-time vine-growers in these groups ( 5 of the 6 part-time vine-growers in the sample). Parttime vine-growers are not differentiated from the others by a significantly smaller area per MPU, as might have been expected. However close analysis of the division of labor in the holding shows that in every holding surveyed, it is the vineyard manager who virtually always drives the tractor, the other workers being given manual jobs. In the case of vine-growers with other business activities, integral chemical weed control, sometimes associated with minimum tillage, can been seen as a way of having "clean" vines even if the tractor is not available for tillage.

In the final analysis, this approach supports the idea that the field characteristics play an essential part in the adoption of a weed control method. But, at the same time, it limits the impact of the field constraints, which makes sense in the particular context of the overall characteristics of the holding and in particular of the adjustment of the size of the workforce and the number of hours worked to the size of the holding.
Table VIII. Distribution of weed control methods between cooperative wineries.

\begin{tabular}{lcccccc}
\hline & \multicolumn{2}{c}{ Winery A } & \multicolumn{2}{c}{ Winery B } & \multicolumn{2}{c}{ Total } \\
\cline { 2 - 7 } & ha & $\%$ practice & ha & $\%$ practice & ha & $\%$ practice \\
\hline M1 & 77 & 62 & 47 & 38 & 125 & 100 \\
M2 & 76 & 24 & 235 & 76 & 311 & 100 \\
Total & 153 & 35 & 283 & 65 & 436 & 100 \\
\hline
\end{tabular}

Table IX. Distribution of weed control methods in the two cooperative wineries.

\begin{tabular}{lcccc}
\hline & \multicolumn{2}{c}{ Winery A } & \multicolumn{2}{c}{ Winery B } \\
\cline { 2 - 5 } & ha & \% of winery & ha & \% of winery \\
\hline M1 & 77 & 51 & 47 & 17 \\
M2 & 76 & 49 & 235 & 83 \\
Total & 153 & 100 & 283 & 100 \\
\hline
\end{tabular}

\subsection{Distribution of weed control methods by co-operative winery membership}

Membership of a co-operative winery explains part of the distribution of the holdings between the different groups (Tab. VII). The vine-growers belonging to winery B are distributed 50/50 between methods M2a and M2b. Half the vinegrowers belonging to winery A use M1 methods.

This distribution is reflected in terms of area. In our sample, $62 \%$ of the area under integral chemical weed control and only $24 \%$ of the area under partial chemical weed control are cultivated by vine-growers belonging to winery A (Tab. VIII). These areas represent $51 \%$ and $49 \%$, respectively, of the total area under vines of the members of this winery (Tab. IX). In winery $\mathrm{B}$, the percentage of the area under integral chemical weed control is much smaller than that under partial chemical weed control.

This is explained by the structure of the sample, which shows the effect of winery A holdings that have made little change to their grape varieties, as was expected, and which gives greater weight to vine-growers with a small workforce (those with other business activities) in this winery. 


\section{DISCUSSION}

\subsection{Appropriate structuring levels of the diversity of practices}

In this study, we differentiated the weed control practices by intensity of herbicide use. We thus distinguished between integral chemical weed control (M1 methods), characterized by the use of herbicides on the whole field, and partial chemical weed control (method M2) for which herbicide use is limited to the vine rows (sub-method M2b) and possibly part of the interrows (sub-method M2a). In the sample of holdings surveyed, the three hypothesized levels of structuring - the field, the farm holding and the co-operative winery - affect the observed diversity of the practices and its spatial distribution.

The field characteristics related to inter-row width explain the most important part of the distribution of practices between integral and partial chemical weed control methods, whereas choosing between partial weed control sub-methods cannot be explained by the field level variables. In particular, with the typology of soil and the 1/100 000 map used, soil type does not appear to be a determinant criterion to differentiate the practices. Nevertheless, further studies with more precise soil data are required to confirm this result.

The results at the field level also show that the inter-row width related field constraint is not absolute, as it is not taken into account in the same way by all the vine-growers. Most of them have equipment to work their fields with narrow interrows, and a certain number of them in fact do so. The choice of integral chemical weed control for such fields seems to be because of genuine difficulties in working these fields as much as for economic reasons, which make them a lower priority in terms of work allocation. According to our survey, such fields are usually unproductive because their vines are very old and not as well paid per hectoliter because of the scale of payments of the studied co-operatives, and they are therefore waiting to be grubbed up sooner or later. In addition, the symmetry between vines with narrow inter-rows under integral chemical weed control and those with wider inter-rows under partial chemical weed control may be misleading. From a previous survey of winery A holdings [28], we know that in 1995 a large part of the vines with wide inter-rows were under integral chemical weed control. These results confirm that field constraints are relative, on the one hand, to the characteristics of the holdings fields are part of and, on the other hand, to the economic context in which holdings are involved.

To take the fullest account of the diversity of the weed control practices, it thus appears necessary to focus on the farm holding. Replacement of grape variety, size of holdings and available workforce can in fact be used to differentiate the holdings by choice of practices at the most detailed level (M1, M2a or M2b). There is a tendency for holdings with the most intensive practices in terms of herbicide use over the whole of their vineyard to be the most constrained in terms of vineyard structure and/or available workforce. A vineyard structure where there has been change of variety argues in favor of tillage-based weed control practices, but even in such a situation the existence of a large structure can lead to a search for ways to simplify the work and consequently to more intensive use of herbicides.
Lastly, by affecting the structure of its members' vineyards through its plantation subsidy policy and its payment scale, the co-operative seems to induce a marked differentiation in relation to the structure of the sample which influences the spatial distribution of the practices.

\subsection{Appropriate level of data spatialization}

In the final analysis, these results underline some of the problems to be resolved if one wants to be able to propose a method of spatializing the practices in a water catchment aimed at assigning a practice or a probability of practice to precisely localized fields.

To do so, a first step is to localize the dominant field constraints related to the election of weed control practice. In the case of vine, localizing the field of vine with narrow inter-rows can be achieved by very high spatial resolution remote sensing [32]. This can be used to attribute the use of integral chemical weed control to most of the fields concerned, with a low probability of error.

To obtain more precise data on the probability of use of each weed control method and sub-method in each of the fields over the studied catchment, a second step would be to access databases of individual data on farm holdings and on their field structure. The required data are regularly updated in the farm censuses and the data banks of the co-operative wineries. In theory, they could be coupled with the cadastral data, but these data are private and access can be refused.

However, one should not overestimate these difficulties as the scale of the precisely localized field is not necessarily the most appropriate level of spatialization of the practices. Simulation data on an experimental sub-catchment in the Peyne Valley tend, in fact, to show that the pollution process is sensitive only to a distribution of practices in large and contrasted patches [24].

One therefore needs to know whether such a visible pattern arises from the spatial distribution of the practices, and if this is the case, which of the three levels of organization primarily determine it.

The supply basin of the co-operative winery can appear to be an important level of spatialization of the practices when there are major differences in the structure of the holdings between the members of different wineries, reflected in very different proportions of each practice at the level of the supply basins, as is the case with the wineries studied.

In contrast, the holding and its land appear to be a level of spatialization of weed control methods that is of less interest. Our survey showed a high fragmentation and dispersion of the lands of the farm holdings. This will be reflected in a scattering of practices over the co-operatives' supply basins.

At the field level, only a preferential localization of the field constraints will affect the pollution process. This will frequently be observed in $\mathrm{AOC}$ areas as the use of the appellation, which makes it necessary to keep a certain percentage of the vines in traditional varieties, can lead to old vines being kept in production in these areas. It can also be observed when the presence of severely constrained geomorphological units leads to the grape varieties being changed first and foremost in the most favorable areas and hence to the association of vines with 
narrow inter-rows and the most severely constrained units. Such is the case in the Peyne Valley, for instance, with what are known as terraced areas. These are characterized by small, steeply sloping fields separated by a large bank [29], and replanting them in vines with wide inter-rows would require consolidation accompanied by major leveling work.

If the field constraints are not preferentially localized, an assessment of the respective percentages of the different weed control practices on the scale of the co-operative's supply basin will probably suffice. It can be conducted by means of sample surveys, or from a photo interpretation to estimate the area under vines with narrow inter-rows, then by using the latest farm census data and recalibrating the relationship between type of holding and weed control practice. In many situations, it can be supposed that a good approximation of the supply basin of the co-operative winery can be given by the area of land under vines within the commune(s). The diversity of the holdings belonging to a co-operative winery can then be approximated from the data of the latest farm census.

A difficulty that should not be overlooked in this assessment relates to changes in the context in which the holdings are situated, as this can lead to major changes in their soil management practices. The slow rate of change of the spatial structure of the vineyard should be seen in contrast to the possibility of rapid changes in technical choices, under the influence of payment variations (market fluctuations), legal provisions or changes in technical advice. This is demonstrated by the changes in the practices in winery A emphasized above. At this point, we reach the limits of the spatial approach.

Acknowledgements: We thank François Papy and Marc Voltz for reading the different versions of this article and Garth Evans for the English translation. The research was funded by the Ministry of Research, within the framework of a joint research program on water and environment, and by the INRA-DADP program. This work was also partially financed by the Ministry of Environment, Town and Country Planning, within the framework of the GESSOL program.

\section{REFERENCES}

[1] Agence de l'eau RMC, Composés phytosanitaires dans les eaux superficielles et souterraines du bassin Rhône-MéditerranéeCorse : campagne 1997, Agence de l'Eau Rhône-MéditerranéeCorse, 2000.

[2] Agence de l'eau RMC, Composés phytosanitaires dans les eaux superficielles et souterraines du bassin Rhône-MéditerranéeCorse : campagne 1999, Agence de l'eau Rhône-MediterranéeCorse, 2002.

[3] Aubry C., Biarnès A., Maxime F., Papy F., Modélisation de l'organisation technique de la production dans l'exploitation agricole : la constitution de systèmes de culture, Étud. Rech. Syst. Agraires Dév. 31 (1998) 25-43.

[4] Beaujouan V., Durand P., Ruiz L., Modelling the effect of the spatial distribution of agricultural pratices on nitrogen fluxes in rural catchment, Ecol. Model. 137 (2001) 93-105.

[5] Bellon S., Lescouret F., Calmet J.P., Characterisation of apple orchard mangement systems in a French Mediterranean Vulnerable Zone, Agronomie 21 (2001) 203-213.
[6] Bonfils : Carte pédologique de France au $1 / 100^{\circ} 000$; feuille de Lodève, SESCPF INRA, 1993.

[7] Caneill J., Le Bail M., Contribution de l'agronome à la gestion d'un bassin d'approvisionnement, in: Nicolas F., Valceschini E. (Eds.), Agro-alimentaire : une économie de la qualité, INRA - Economica, Paris, 1995, pp. 391-399.

[8] Capillon A., Typologie des exploitations agricoles, contribution à l'étude régionale des problèmes techniques, Thèse de doctorat, INA-PG, Paris, 1993.

[9] Colin F., Puech C., de Marsily G., Relation between triazine flux, catchment topography and distance between maize fields and the drainage network, J. Hydrol. 236 (2000) 139-152.

[10] Dounias I., Aubry C., Capillon A., Decision-making processes for crop management on African farms. Modelling from a case study of cotton crops in northern Cameroon, Agric. Syst. 73 (2002) 233260 .

[11] DRAF : Recensement agricole 2000. Viticulture, Agreste Languedoc-Roussillon, 2002.

[12] Gras R., Benoit M., Deffontaines J.P., Duru M., Lafarge M., Langlet A., Osty P.L., Le fait technique en agronomie, Alternatives rurales, L'harmattan, Paris, 1989.

[13] Jarrige F., Touzard J.M., Les mutations de l'organisation coopérative à travers l'évolution de ses règles, Rev. Int. Econ. Soc. RECMA (2001) 63-41.

[14] Katerji N., Bruckler L., Debaeke P., L'eau, l'agriculture et l'environnement : analyse introductive à une réflexion sur la contribution de la recherche agronomique, Courr. Environ. INRA 46 (2002) 39_ 50 .

[15] Lagacherie P., Collin-Bellier C., Goma-Fortin N., Évaluation et analyse de la variabilité spatiale de la mortalité des ceps dans un vignoble languedocien à partir de photographies aériennes à haute résolution, J. Int. Sci. Vigne Vin 35 (2001) 141-148.

[16] Lagacherie P., Louchart X., Moussa R., Rio P., Frot E., Le Forner S., Andrieux P., Voltz M., Essai de couplage d'un modèle hydrologique et d'un modèle agro-économique en vue d'analyser l'impact des mesures d'orientation de la viticulture méridionale sur la qualité des eaux à l'exutoire d'un bassin versant viticole, in: Organisation spatiale et conduite des culture, AIP Ecospace INRA, Paris, 1999.

[17] Landais E., Deffontaines J.P., Benoît M., Les pratiques des agriculteurs. Point de vue sur un courant nouveau de la recherche agronomique, Étud. Rur. 109 (1989) 125-158.

[18] Le Bail M., Le bassin d'approvisionnement : territoire de la gestion agronomique de la qualité des productions végétales, C.R. Acad. Agric. France (2003) to be published.

[19] Lennartz B., Louchard X., Voltz M., Andrieux P., Diuron and simazine losses to runoff water in mediterranean vineyards, J. Environ. Qual. 26 (1997) 1493-1502.

[20] Louchart X., Voltz M., Andrieux P., Herbicides Run-off from Field to Catchment Scale in a Mediterranean Area, in: $24^{\mathrm{e}}$ Congrès EGS, 1999.

[21] Louchart X., Causeret F., Dejean C., Andrieux P., Lagacherie P., Rio P., Voltz M., Première évaluation des risques et origines de la pollution diffuse des eaux de surface par les pesticides en zone viticole languedocienne, INRA, Paris, 1997.

[22] Milleville P., Conduite des cultures pluviales et organisation du travail en Afrique soudano-sahélienne : des déterminants climatiques aux rapports sociaux de production, in: Biarnès A. (Ed.), La 
conduite du champ cultivé, Colloques et séminaires, Orstom éditions, Paris, 1998, pp. 165-180.

[23] Moussa R., Voltz M., Andrieux P., Hydrological modelling of flood events in a farmed Mediterranean catchment, Documents techniques en hydrologie, Unesco Publications, 2001.

[24] Moussa R., Voltz M., Andrieux P., Effects of the spatial organization of agricultural management on the hydrological behavior of a farmed catchment during flood events, Hydrol. Process. 16 (2002) 393-412.

[25] Novotny V., Diffuse pollution from agriculture - a worldwide outlook, Water Sci. Technol. 39 (1999) 1-13.

[26] Papy F., Agriculture et organisation du territoire par les exploitations agricoles : enjeux, concepts, question de recherche, C.R. Acad. Agric. France 85 (1999) 233-244.

[27] Papy F., Interdépendance des systèmes de culture dans l'exploitation, in: Malezieux E., Trébuil G., Jaeger M. (Eds.), Modélisation des agro-écosystèmes et aide à la décision, Editions Cirad-Inra, 2001, pp. 51-74.

[28] Rio P., Causeret F., Andrieux P., Dejean C., Frot E., Louchart X., Gérer la pollution par les herbicides : une simulation en milieu viticole méditerranéen, Econ. Rur. 259 (2000) 33-49.

[29] Temple-Boyer E., Les talus, éléments linéaires du paysage méditerranéen (Bassin versant de Roujan, Hérault), Mémoire de mầtrise, Paris I, 2000.

[30] Tomassone R., Danzart M., Daudin J.J., Discrimination et classement, Masson, Paris, 1988.

[31] Touzard J.-M., Laporte J.P., Deux décennies de transition viticole en Languedoc-Roussillon : de la production de masse à une viticulture plurielle, Pôle Sud 9 (1998) 26-47.

[32] Wassenar T., Baret F., Robbez-Masson J.M., Andrieux P., Vineyard identification and description on spatial crop structure by perfield frequency analysis, Int. J. Remote Sens. 23 (2002) 3311-3325. 